\title{
Triterpenoid Saponins from Lippia alba (Mill.) N. E. Brown
}

\author{
Mareni R. Farias, ${ }^{*}, a$ Roberto Pértile, ${ }^{a}$ Melissa M. Correa, ${ }^{a}$ Maria Tereza R. de Almeida, ${ }^{b}$ \\ Jorge A. Palermo ${ }^{b}$ and Eloir P. Schenkel ${ }^{a}$ \\ ${ }^{a}$ Programa de Pós-graduação em Farmácia, Universidade Federal de Santa Catarina, Campus \\ Universitário Trindade, 88040-900 Florianópolis-SC, Brazil and Departamento de Ciências
}

Farmacêuticas, Universidade Federal de Santa Catarina, 88040-900 Florianópolis-SC, Brazil

${ }^{b}$ Departamento de Química Orgánica, Facultad de Ciencias Exactas y Naturales, Universidad de

Buenos Aires, Ciudad Universitaria Pab.2, C1428EGA, Buenos Aires, Argentina

\begin{abstract}
Das folhas de Lippia alba foram isoladas duas saponinas. As estruturas destas saponinas foram estabelecidas empregando métodos espectroscópicos, principalmente RMN mono e bidimensional e espectrometria de massas. Estes novos compostos foram caracterizados como ácido 3-O- $\beta$-D-glucopiranosil-28- $O$ - $(\alpha$-L-rhamnopiranosil- $(1 \rightarrow 3)-\beta$-D-xilopiranosil- $(1 \rightarrow 4)$ $\alpha$-L-rhamnopiranosil-(1 $\rightarrow 2)$ - $\alpha$-L-arabinopiranosil)-16 $\alpha, 23$-di-hidróxi-olean-12-en-28-óico, designada Lippiasaponina I (2) e como ácido 3- $O$ - $\beta$-D-glucopiranosil-28- $O$-( $\alpha$-L-rhamnopiranosil$(1 \rightarrow 3)$ - $\beta$-D-xilopiranosil-( $1 \rightarrow 4)$ - $\alpha$-L-rhamnopiranosil-( $1 \rightarrow 3)-\alpha$-L-arabinopiranosil)-16 $\alpha, 23$-dihidróxi-olean-12-en-28-óico, designada Lippiasaponina II (3).
\end{abstract}

Two saponins were isolated from the leaves of Lippia alba. Their structures were established using one- and two-dimensional NMR spectroscopy and mass spectrometry. These new compounds were elucidated as $3-O-\beta-\mathrm{D}$-glucopyranosyl-28- $O$ - $(\alpha-\mathrm{L}-$-rhamnopyranosyl- $(1 \rightarrow 3)-\beta-\mathrm{D}$ xylopyranosyl-( $(1 \rightarrow 4)-\alpha$-L-rhamnopyranosyl-( $1 \rightarrow 2)$ - $\alpha$-L-arabinopyranosyl)-16 $\alpha, 23$-dihydroxy-olean-12-en-28-oic acid, named as Lippiasaponin I (2) and as 3-O- $\beta$-D-glucopyranosyl-28- $O$ $(\alpha$-L-rhamnopyranosyl- $(1 \rightarrow 3)-\beta$-D-xylopyranosyl- $(1 \rightarrow 4)-\alpha$-L-rhamnopyranosyl- $(1 \rightarrow 3)$ - $\alpha$-Larabinopyranosyl)-16 $\alpha, 23$-dihydroxy-olean-12-en-28-oic acid, named Lippiasaponin II (3).

Keywords: Lippia alba, verbenaceae, saponins

\section{Introduction}

Lippia alba (Mill.) N. E. Brown (Verbenaceae) is a shrub widely distributed throughout South America and it is popularly known as 'cidreira' or 'false melissa', designation derived from other medicinal plants (Melissa officinalis L. and Cymbopogon citratus (DC) Stapf.) also used in the popular medicine in cases of respiratory distress. Traditionally the tea from its leaves is largely utilized in popular medicine from all Brazilian regions as a tranquilizer and also in gastrointestinal and respiratory disorders. From the pharmacological point of view, antifungal activity was reported for hydroalcoholic extracts. ${ }^{1,2}$ Inhibition of HSV-1 (strain 29R/acyclovir resistant) was reported for the $n$-butanol fraction, and antipoliovirus activity for the ethyl acetate fraction. ${ }^{3}$ In addition, sedative and myorelaxant

*e-mail: marenif@yahoo.com.br effects in vivo were reported for the hydroalcoholic extracts ${ }^{4}$ and antiulcerogenic activity was described for the leaves' infusion. $^{5}$

Most chemical studies of $L$. alba are related to the essential oil composition and at least three chemotypes have been proposed based on the volatile chemical composition of its leaves. ${ }^{6}$ For the aerial parts, the presence of flavonoids, ${ }^{7}$ iridoid and phenylethanoid glycosides ${ }^{8}$ was reported. For a detailed review see Pascual et al. ${ }^{9}$ and references therein quoted.

In the present work, we report the isolation and structural characterization of two new saponins. To the best of our knowledge, the presence of saponins in Lippia alba has not been previously reported. The complete hydrogen and carbon assignments of the new compounds was accomplished using 2D NMR experiments including ${ }^{1} \mathrm{H},{ }^{1} \mathrm{H}-\mathrm{COSY}, \mathrm{RCT},{ }^{13} \mathrm{C}$, DEPT 90 and 135 , HSQC, HMQC and $\mathrm{HMBC}$. 


\section{Results and Discussion}

Solvent partition and chromatographic procedures allowed the isolation of the main triterpenoid saponins from the aerial parts of L. alba: Lippiasaponin I (2) and Lippiasaponin II (3). Basic hydrolysis of a mixture of $\mathbf{2}$ and $\mathbf{3}$ afforded only one prosapogenin (1).

\section{Compound 1}

The ${ }^{13} \mathrm{C}$ NMR spectrum of the prosapogenin (1) showed 36 signals, whereas the DEPT spectrum revealed 6 methyls, 11 methylenes, 11 methines and 8 quaternary carbon atoms. Six carbons could clearly assigned to the sugar moiety, identified as $\beta$-glucopyranose by the NMR signals of the anomeric position $\left(\delta{ }^{13} \mathrm{C} 105.8 ; \delta{ }^{1} \mathrm{H} 4.39\right)$.

The ${ }^{1} \mathrm{HNMR}$ and ${ }^{13} \mathrm{C}$ NMR spectrum of the prosapogenin 1 in $\mathrm{CD}_{3} \mathrm{OD}$ displayed characteristic signals of a triterpene aglycone derived from oleanolic acid, showing a triplet at $\delta 5.29$, which correlated in the HSQC spectrum with an olefinic carbon doublet at $\delta$ 123.4, assigned to C-12. Six three-hydrogen singlets at $\delta 0.70, \delta 0.98, \delta 0.79, \delta 1.38$, $\delta 0.87$ and $\delta 0.96$ could be assigned to the $\mathrm{C}-24, \mathrm{C}-25$, C-26, C-27, C-29 and C-30 methyl groups respectively. A signal at $\delta 181.3$ in the ${ }^{13} \mathrm{C}$ NMR spectrum was assigned to the carboxilic acid at $\mathrm{C}-28{ }^{10}$

Three oxygenated carbons were observed at $\delta 83.5$ $(\mathrm{CH}), \delta 64.9\left(\mathrm{CH}_{2}\right)$ and $\delta 75.3(\mathrm{CH})$. The former was assigned as glycosidated $\mathrm{C}-3$, confirmed by the HMBC correlation between the anomeric hydrogen at $\delta 4.39$ and the carbon at $\delta$ 83.5. The oxygenated carbon at $\delta 65.0$ $\left(\mathrm{CH}_{2}\right)$, in principle could be assigned to $\mathrm{C}-23$ or $\mathrm{C}-24 .{ }^{10}$

This hydroxymethylene group was assigned to C-23 considering the ${ }^{13} \mathrm{C}$ NMR chemical shifs of the methyl groups. It is reported that a hydroxymethylene group at the $4 \alpha$-position (C-23) provokes a shielding for the $4 \beta$-methyl group (C-24) to $c a . \delta 11-13 .{ }^{11}$ The shielded methyl group $(\delta 13.4, \mathrm{~s})$ was assignable to the $4 \beta$-methyl group (C-24), thus, this hydroxyl was linked at C-23 $(\delta 65.0)$.

The remaining oxygenated carbon at $\delta 75.3(\mathrm{CH})$ was linked to the hydrogen at $\delta 4.45(\mathrm{~m})$. The COSY spectrum showed that this hydrogen was coupled to hydrogens at $\delta 1.35$ and $\delta 1.85$, assigned to $\mathrm{C}-15$ by HMBC correlations, thus unambiguously locating this hydroxyl group at C-16. The $16 \alpha$-configuration was evident from the small $J$ values of $\mathrm{H}-16$ (broad multiplet at $\delta 4.45$ ) in the ${ }^{1} \mathrm{H}$ NMR spectrum, characteristic of an equatorial hydrogen.

Therefore, the structure of $\mathbf{1}$ was elucidated as 3-O- $\beta$ D-glucopyranosyl-16 $\alpha$-23-dihydroxy-olean-12-en-28-oic acid. Total carbon and hydrogen assignments are shown on Table 1.

\section{Compound 2}

The FAB MS (positive ion mode) of compound 2 displayed a quasi-molecular ion peak at $m / z, 1229\left[\mathrm{M}+\mathrm{Na}^{+}\right]$ suggesting a molecular formula of $\mathrm{C}_{58} \mathrm{H}_{94} \mathrm{O}_{26}$. In addition, a fragment ion at $\mathrm{m} / \mathrm{z}, 1050$ indicated the loss of an hexose moiety.

The ${ }^{13} \mathrm{C}$ NMR spectrum of $\mathbf{2}$ showed 58 signals, whereas the DEPT spectrum revealed 8 methyls, 13 methylenes, 29 methines and 8 quaternary carbon atoms. The comparison of the ${ }^{1} \mathrm{H}$ and ${ }^{13} \mathrm{C}$ data (Table 1) indicated the same partial structure of compound $\mathbf{1}$. The major differences were observed at C-28 ( $\delta$ 175.6) and the presence of five anomeric carbons instead of one. The shielding of C-28 was attributed to glycosylation of the carboxyl group. ${ }^{10}$

The ${ }^{13} \mathrm{C}$ NMR signals of the four additional anomeric carbons were located at $\delta 94.0, \delta 101.4, \delta 102.5$ and $\delta 106.5$ and correlated to anomeric hydrogens at $\delta 5.60, \delta 5.03$, $\delta 5.13$ and $\delta 4.53$ respectively in the HSQC experiments (Table 1).

HMBC, COSY, RCT, and 2D $J$-Resolved spectra were used for the complete assignment of the resonances of each monosaccharide moiety, starting from the anomeric hydrogens.

The analysis of these spectra revealed the presence of a $\beta$-D-xylose $\left(J_{\mathrm{H}-1, \mathrm{H}-2}=7.7 \mathrm{~Hz}\right)$, an $\alpha$-L-arabinose in a predominant ${ }^{1} \mathrm{C}_{4}$ conformation $\left({ }^{3} \mathrm{~J}_{\mathrm{H}-1, \mathrm{H}-2}=3.8 \mathrm{~Hz}\right)^{12}$ and two $\alpha$-rhamnoses $\left(J_{\mathrm{H}-1, \mathrm{H}-2}=1.6 \mathrm{~Hz}\right.$ and $\left.J_{\mathrm{H}-1, \mathrm{H}-2}=1.4 \mathrm{~Hz}\right)$ identified through the observation of COSY correlations between two methyl doublets at $\delta 1.23$ and $\delta 1.29$ and glycosidic hydrogens at $\delta 3.99$ and 3.68, respectively. Sequencing of the glycosidic chains was achieved by analysis of HMBC experiments. For the tetraglycosidic chain linked to the carboxylic C-28 of the aglycone, the HMBC showed cross-peaks between $\mathrm{H}-1$ ( $\delta$ 5.13) of a terminal rhamnose and C-3 $(\delta 84.1)$ of xylose, between H-1 of xylose $(\delta 4.53)$ and $\mathrm{C}-4(\delta 83.4)$ of an inner rhamnose, between $\mathrm{H}-1(\delta 5.03)$ of an inner rhamnose and C-2 (75.8) of arabinose and between $\mathrm{H}-1(\delta 5.60)$ of arabinose and $\mathrm{C}-28(\delta$ 175.6). This last correlation confirmed the linkage between $\mathrm{C}-2$ of arabinose and $\mathrm{C}-1$ of inner rhamnose. The assignment of $\mathrm{D}$ or $\mathrm{L}$ configurations was confirmed by GC (Gas Chromatography) of the corresponding acetylated 1-deoxy-1-(2-hydroxypropylamino) alditols, prepared from the monosaccharides obtained by acid hydrolysis of compound 2 , and co-injection with authentic standards. ${ }^{13}$ Therefore, compound 2 was identified as $3-O-\beta-\mathrm{D}$ glucopyranosyl-28- $O$ - $(\alpha$-L-rhamnopyranosyl- $(1 \rightarrow 3)-\beta-\mathrm{D}-$ xylopyranosyl- $(1 \rightarrow 4)$ - $\alpha$-L-rhamnopyranosyl- $(1 \rightarrow 2)-\alpha$-Larabinopyranosyl)-16 $\alpha, 23$-dihydroxy-olean-12-en-28-oic 
Table 1. ${ }^{13} \mathrm{C}$ NMR and ${ }^{1} \mathrm{H}$ NMR data of Prosapogenin, Lippiasaponin I and Lippiasaponin II (in $\mathrm{CD}_{3} \mathrm{OD}$ )

\begin{tabular}{|c|c|c|c|c|c|c|c|}
\hline \multirow[b]{2}{*}{ Attribution } & \multirow[b]{2}{*}{ DEPT } & \multicolumn{2}{|c|}{ Prosapogenin (1) } & \multicolumn{2}{|c|}{ Lippiasaponin I (2) } & \multicolumn{2}{|c|}{ Lippiasaponin II (3) } \\
\hline & & $\delta_{\mathrm{C}}$ & $\delta_{\mathrm{H}}(J$ in $\mathrm{Hz})$ & $\delta_{\mathrm{C}}$ & $\delta_{\mathrm{H}}(\mathrm{J}$ in $\mathrm{Hz})$ & $\delta_{\mathrm{C}}$ & $\delta_{\mathrm{H}}(J$ in $\mathrm{Hz})$ \\
\hline \multicolumn{8}{|l|}{ Aglicone } \\
\hline 1 & $\mathrm{CH}_{2}$ & 39.6 & $\begin{array}{l}0.98 \mathrm{~m} \\
1.62 \mathrm{~m}\end{array}$ & 39.6 & $\begin{array}{l}1.61 \mathrm{~m} \\
1.65 \mathrm{~m}\end{array}$ & 39.6 & $\begin{array}{l}0.96 \mathrm{~m} \\
1.62 \mathrm{~m}\end{array}$ \\
\hline 2 & $\mathrm{CH}_{2}$ & 26.4 & $\begin{array}{l}1.74 \mathrm{~m} \\
1.95 \mathrm{~m}\end{array}$ & 26.3 & $\begin{array}{l}1.90 \mathrm{~m} \\
1.90 \mathrm{~m}\end{array}$ & 26.4 & $\begin{array}{l}1.75 \mathrm{~m} \\
1.93 \mathrm{~m}\end{array}$ \\
\hline 3 & $\mathrm{CH}$ & 83.5 & $3.63 \mathrm{~m} *$ & 83.6 & $3.64 \mathrm{~m} *$ & 83.8 & $3.66 \mathrm{dd}(5.4,12.0)$ \\
\hline 4 & $\mathrm{C}$ & 43.9 & - & 43.5 & - & 43.9 & - \\
\hline 5 & $\mathrm{CH}$ & 48.3 & $1.23 \mathrm{~m}$ & 48.4 & $1.23 \mathrm{~d}(6.2)$ & 48.5 & $1.20 \mathrm{~d}(4.2)$ \\
\hline 6 & $\mathrm{CH}_{2}$ & 18.9 & $\begin{array}{l}1.37 \mathrm{~m} \\
1.48 \mathrm{~m}\end{array}$ & 19.0 & $\begin{array}{l}1.37 \mathrm{~m} \\
1.47 \mathrm{~m}\end{array}$ & 19.2 & $\begin{array}{l}1.37 \mathrm{~m} \\
1.47 \mathrm{~m}\end{array}$ \\
\hline 7 & $\mathrm{CH}_{2}$ & 33.8 & $\begin{array}{l}1.28 \mathrm{~m} \\
1.64 \mathrm{~m}\end{array}$ & 33.7 & $\begin{array}{l}1.37 \mathrm{~m} \\
1.61 \mathrm{~m}\end{array}$ & 33.7 & $\begin{array}{l}1.48 \mathrm{~m} \\
1.58 \mathrm{~m}\end{array}$ \\
\hline 8 & $\mathrm{C}$ & 40.6 & - & 40.7 & - & 40.8 & - \\
\hline 9 & $\mathrm{CH}$ & 48.2 & $1.69 \mathrm{~m}$ & 48.1 & $1.67 \mathrm{~m}$ & 48.1 & $1.67 \mathrm{~m}$ \\
\hline 10 & $\mathrm{C}$ & 37.7 & - & 37.6 & - & 37.7 & - \\
\hline 11 & $\mathrm{CH}_{2}$ & 24.5 & $\begin{array}{l}1.90 \mathrm{~m} \\
1.90 \mathrm{~m}\end{array}$ & 24.5 & $\begin{array}{l}1.90 \mathrm{~m} \\
1.90 \mathrm{~m}\end{array}$ & 24.5 & $\begin{array}{l}1.90 \mathrm{~m} \\
1.90 \mathrm{~m}\end{array}$ \\
\hline 12 & $\mathrm{CH}$ & 123.4 & $5.29 \mathrm{br} \mathrm{t}$ & 123.7 & $5.34 \mathrm{t}(3.4)$ & 123.5 & $5.32 \mathrm{t}(3.5)$ \\
\hline 13 & $\mathrm{C}$ & 145.2 & - & 145.0 & - & 144.8 & - \\
\hline 14 & $\mathrm{C}$ & 42.8 & - & 42.3 & - & 42.8 & - \\
\hline 15 & $\mathrm{CH}_{2}$ & 36.2 & $\begin{array}{l}1.35 \mathrm{~m} \\
1.85 \mathrm{~m}\end{array}$ & 36.4 & $\begin{array}{l}1.15 \mathrm{~m} \\
1.39 \mathrm{~m}\end{array}$ & 36.6 & $\begin{array}{l}1.47 \mathrm{~m} \\
1.67 \mathrm{~m}\end{array}$ \\
\hline 16 & $\mathrm{CH}$ & 75.3 & $4.45 \mathrm{~m}$ & 74.6 & 4.48 br t & 74.5 & $4.46 \mathrm{~s}$ \\
\hline 17 & $\mathrm{C}$ & 49.6 & - & 50.0 & - & 50.3 & - \\
\hline 18 & $\mathrm{CH}$ & 42.1 & $3.00 \mathrm{dd}(4.0,12.0)$ & 42.1 & $3.02 \mathrm{dd}(3.9,12.0)$ & 42.2 & $2.96 \mathrm{dd}(4.0,12.0)$ \\
\hline 19 & $\mathrm{CH}_{2}$ & 47.7 & $\begin{array}{c}1.02 \mathrm{~m} \\
2.28 \mathrm{t}(12.0)\end{array}$ & 47.6 & $\begin{array}{c}1.04 \mathrm{dd}(12.0,3.9) \\
2.27 \mathrm{t}(12.0)\end{array}$ & 47.9 & $\begin{array}{c}1.05 \mathrm{dd}(4.0,12.0) \\
2.28 \mathrm{t}(12.0)\end{array}$ \\
\hline 20 & $\mathrm{C}$ & 31.4 & - & 32.0 & - & 31.3 & - \\
\hline 21 & $\mathrm{CH}_{2}$ & 36.6 & $\begin{array}{l}1.14 \mathrm{~m} \\
1.93 \mathrm{~m}\end{array}$ & 36.4 & $\begin{array}{c}1.43 \mathrm{dd}(3.9,12.0) \\
1.75 \mathrm{~m}\end{array}$ & 36.6 & $\begin{array}{l}1.16 \mathrm{~m} \\
1.93 \mathrm{~m}\end{array}$ \\
\hline 22 & $\mathrm{CH}_{2}$ & 32.7 & $\begin{array}{l}1.76 \mathrm{~m} \\
1.90 \mathrm{~m}\end{array}$ & 31.9 & $\begin{array}{l}1.90 \mathrm{~m} \\
1.90 \mathrm{~m}\end{array}$ & 32.1 & $\begin{array}{l}1.89 \mathrm{~m} \\
1.92 \mathrm{~m}\end{array}$ \\
\hline 23 & $\mathrm{CH}_{2}$ & 65.0 & $\begin{array}{l}3.27 \mathrm{~m} \\
3.62 \mathrm{~m}\end{array}$ & 65.2 & $\begin{array}{l}3.36 \mathrm{~d}(12.0) \\
3.62 \mathrm{~d}(12.0)\end{array}$ & 65.4 & $\begin{array}{c}3.30 \mathrm{~m} \\
3.64 \mathrm{~d}(12.0)\end{array}$ \\
\hline 24 & $\mathrm{CH}_{3}$ & 13.4 & $0.70 \mathrm{~s}$ & 13.5 & $0.72 \mathrm{~s}$ & 13.6 & $0.74 \mathrm{~s}$ \\
\hline 25 & $\mathrm{CH}_{3}$ & 16.6 & $0.98 \mathrm{~s}$ & 16.6 & $0.99 \mathrm{~s}$ & 16.7 & $0.99 \mathrm{~s}$ \\
\hline 26 & $\mathrm{CH}_{3}$ & 17.8 & $0.79 \mathrm{~s}$ & 18.0 & $0.77 \mathrm{~s}$ & 17.8 & $0.77 \mathrm{~s}$ \\
\hline 27 & $\mathrm{CH}_{3}$ & 27.3 & $1.38 \mathrm{~s}$ & 27.3 & $1.37 \mathrm{~s}$ & 27.2 & $1.35 \mathrm{~s}$ \\
\hline 28 & $\mathrm{C}$ & 181.3 & -- & 175.6 & - & 177.1 & - \\
\hline 29 & $\mathrm{CH}_{3}$ & 33.4 & $0.87 \mathrm{~m}$ & 33.3 & $0.87 \mathrm{~s}$ & 33.3 & $0.87 \mathrm{~s}$ \\
\hline 30 & $\mathrm{CH}_{3}$ & 24.9 & $0.96 \mathrm{~s}$ & 25.1 & $0.96 \mathrm{~s}$ & 24.9 & $0.94 \mathrm{~s}$ \\
\hline \multicolumn{8}{|c|}{ 3-O-sugar } \\
\hline Gly & & & & & & & \\
\hline 1 & $\mathrm{CH}$ & 105.8 & $4.39 \mathrm{~d}(7.7)$ & 105.7 & $4.40 \mathrm{~d}(7.7)$ & 105.7 & $4.39 \mathrm{~d}(7.7)$ \\
\hline 2 & $\mathrm{CH}$ & 75.7 & $3.16 \mathrm{t}(8.2)$ & 75.6 & $3.17 \mathrm{t}(8.0)$ & 75.7 & $3.16 \mathrm{t}(8.8)$ \\
\hline 3 & $\mathrm{CH}$ & 78.4 & $3.34 \mathrm{~m}^{*}$ & 78.3 & $3.35 \mathrm{t}(8.0)$ & 78.3 & $3.33 \mathrm{t}(8.8)$ \\
\hline 4 & $\mathrm{CH}$ & 71.6 & $3.27 \mathrm{~m}^{*}$ & 71.6 & $3.29 \mathrm{~m}$ & 71.6 & $3.28 \mathrm{t}(8.8)$ \\
\hline 5 & $\mathrm{CH}$ & 77.8 & $3.27 \mathrm{~m}^{*}$ & 77.7 & $3.27 \mathrm{~m}$ & 77.8 & $3.26 \mathrm{~m}$ \\
\hline 6 & $\mathrm{CH}_{2}$ & 62.8 & $\begin{array}{c}3.67 \mathrm{~m}^{*} \\
3.83 \mathrm{dd}(3.2,10.0)\end{array}$ & 62.7 & $\begin{array}{c}3.70 \mathrm{~m} \\
3.81 \mathrm{dd}(3.5,12.0)\end{array}$ & 62.7 & $\begin{array}{c}3.68 \mathrm{dd}(5.4,12.0) \\
3.82 \mathrm{~m}\end{array}$ \\
\hline
\end{tabular}


Table 1. continuation

\begin{tabular}{|c|c|c|c|c|c|}
\hline & & 28-O-sugars & & & \\
\hline \multicolumn{6}{|c|}{ Ara } \\
\hline 1 & $\mathrm{CH}$ & 94.0 & $5.60 \mathrm{~d}(3.8)$ & 95.5 & $5.43 \mathrm{~d}(5.2)$ \\
\hline 2 & $\mathrm{CH}$ & 75.8 & $3.77 \mathrm{t}(3.8)$ & 77.1 & $3.54 \mathrm{t}(9.5)$ \\
\hline 3 & $\mathrm{CH}$ & 71.2 & $3.86 \mathrm{~m}$ & 76.6 & $3.55 \mathrm{~m}$ \\
\hline 4 & $\mathrm{CH}$ & 67.0 & $3.82 \mathrm{dd}(3.5,9.0)$ & 70.9 & $3.52 \mathrm{~m}$ \\
\hline 5 & $\mathrm{CH}_{2}$ & 63.8 & $\begin{array}{c}3.50 \mathrm{~m} * \\
3.89 \mathrm{dd}(9.0,12.0)\end{array}$ & 66.7 & $\begin{array}{c}3.28 \mathrm{~d}(12.0) \\
3.91 \mathrm{~m}\end{array}$ \\
\hline \multicolumn{6}{|c|}{ Rha I } \\
\hline 1 & $\mathrm{CH}$ & 101.4 & $5.03 \mathrm{~d}(1.4)$ & 101.3 & $5.28 \mathrm{~d}(1.6)$ \\
\hline 2 & $\mathrm{CH}$ & 72.1 & $3.85 \mathrm{~m}$ & 71.9 & $3.91 \mathrm{dd}(1.6,3.4)$ \\
\hline 3 & $\mathrm{CH}$ & 72.4 & $3.84 \mathrm{~m}$ & 72.4 & $3.81 \mathrm{dd}(3.4,9.0)$ \\
\hline 4 & $\mathrm{CH}$ & 83.4 & $3.55 \mathrm{t}(9.0)$ & 84.3 & $3.52 \mathrm{t}(9.0)$ \\
\hline 5 & $\mathrm{CH}$ & 69.0 & $3.68 \mathrm{~m}$ & 69.0 & $3.70 \mathrm{~m}$ \\
\hline 6 & $\mathrm{CH}_{3}$ & 18.1 & $1.29 \mathrm{~d}(6.2)$ & 18.4 & $1.31 \mathrm{~d}(6.2)$ \\
\hline \multicolumn{6}{|c|}{ Xyl } \\
\hline 1 & $\mathrm{CH}$ & 106.5 & $4.53 \mathrm{~d}(7.7)$ & 107.0 & $4.48 \mathrm{~d}(7.7)$ \\
\hline 2 & $\mathrm{CH}$ & 76.2 & $3.34 \mathrm{t}(8.6)$ & 76.4 & $3.37 \mathrm{t}(8.8)$ \\
\hline 3 & $\mathrm{CH}$ & 84.1 & $3.45 \mathrm{t}(8.6)$ & 84.3 & $3.45 \mathrm{t}(8.8)$ \\
\hline 4 & $\mathrm{CH}$ & 69.9 & $3.53 \mathrm{~m}$ & 69.9 & $3.52 \mathrm{~m}$ \\
\hline 5 & $\mathrm{CH}_{2}$ & 67.1 & $\begin{array}{c}3.18 \mathrm{t}(8.3) \\
3.82 \mathrm{~m}\end{array}$ & 67.2 & $\begin{array}{l}3.21 \mathrm{dd}(9.0,12.0) \\
3.86 \mathrm{dd}(5.5,12.0)\end{array}$ \\
\hline \multicolumn{6}{|c|}{ Rha II } \\
\hline 1 & $\mathrm{CH}$ & 102.5 & $5.13 \mathrm{~d}(1.6)$ & 102.6 & $5.13 \mathrm{~d}(1.6)$ \\
\hline 2 & $\mathrm{CH}$ & 72.3 & $3.94 \mathrm{dd}(1.6,3.5)$ & 72.3 & $3.95 \mathrm{dd}(1.6,3.4)$ \\
\hline 3 & $\mathrm{CH}$ & 72.2 & $3.71 \mathrm{dd}(3.5,9.2)$ & 72.2 & $3.71 \mathrm{dd}(3.4,8.8)$ \\
\hline 4 & $\mathrm{CH}$ & 74.0 & $3.38 \mathrm{t}(9.2)$ & 74.0 & $3.37 \mathrm{t}(9.5)$ \\
\hline 5 & $\mathrm{CH}$ & 70.0 & $3.99 \mathrm{dd}(9.2,7.0)$ & 70.0 & $3.99 \mathrm{dd}(5.4,9.5)$ \\
\hline 6 & $\mathrm{CH}_{3}$ & 17.9 & $1.23 \mathrm{~d}(7.0)$ & 17.9 & $1.23 \mathrm{~d}(6.2)$ \\
\hline
\end{tabular}

* overlapping; br = broad.

acid, and named Lippiasaponin I. These sugar assignments are in accordance with literature data. ${ }^{14,15}$

\section{Compound 3}

As in the case of compound 2 , the ${ }^{13} \mathrm{C}$ NMR spectrum of 3 showed 58 signals, whereas the DEPT spectrum revealed 8 methyls, 13 methylenes, 29 methines and 8 quaternary carbon atoms (Table 1).

A comparative analysis of ${ }^{1} \mathrm{H}$ and ${ }^{13} \mathrm{C} \mathrm{NMR}$, and COSY spectra of $\mathbf{3}$, showed great similarities in the chemical shift of both compounds, but some differences in the resonances of the arabinose unit linked at C-28. All ${ }^{13} \mathrm{C}$ signals of this arabinose were deshielding shifted (Table 1). Besides, the $J$ of H-1 Ara ( $\delta 5.43$ ) changed notably from $3.8 \mathrm{~Hz}(2)$ to $5.2 \mathrm{~Hz}(3)$.

The analysis of the COSY, RCT and 2D J-Resolved spectra of compound $\mathbf{3}$ revealed as in compound $\mathbf{2}$, the presence of a $\beta$-D-xylose $\left(J_{\mathrm{H}-1, \mathrm{H}-2}=7.7 \mathrm{~Hz}\right)$, a $\beta$-D-glucose $\left(J_{\mathrm{H}-1, \mathrm{H}-2}=7.7 \mathrm{~Hz}\right)$ and two $\alpha$-rhamnoses $\left(J_{\mathrm{H}-1, \mathrm{H}-2}=1.6 \mathrm{~Hz}\right.$ and $J_{\mathrm{H}-1, \mathrm{H}-2}=1.6 \mathrm{~Hz}$ ). The main difference between 2 and $\mathbf{3}$ was observed in the $\alpha$-L-arabinose unit, which in $\mathbf{3}$ was in a predominant ${ }^{4} \mathrm{C}_{1}$ conformation $\left({ }^{3} \mathrm{~J}_{\mathrm{H}-\mathrm{l}, \mathrm{H}-2}=5.2 \mathrm{~Hz}\right) .{ }^{12}$

For the tetraglycosidic chain linked to the carboxylic C-28 of the aglycone, the HMBC showed cross-peaks between $\mathrm{H}-1$ ( $\delta 5.13)$ of a terminal rhamnose and $\mathrm{C}-3$ $(\delta 84.3)$ of xylose, between $\mathrm{H}-1$ of xylose $(\delta 4.48)$ and C-4 $(\delta 84.3)$ of an inner rhamnose, between $\mathrm{H}-1$ ( $\delta 5.28)$ of an inner rhamnose and C-3 (76.6) of arabinose and between $\mathrm{H}-1(\delta 5.43)$ of arabinose and C-28 ( $\delta$ 177.1). These data indicated the linkage between C-3 of arabinose and C-1 of the inner rhamnose, pointing to the main structural difference between Lippiasaponins I (2) and II (3). A value for the ${ }^{3} J_{\mathrm{H}-1-\mathrm{H}-2}$ coupling of $3.8 \mathrm{~Hz}$ (Ara-H1) was observed in Lippiasaponin I. This data indicated a ${ }^{1} \mathrm{C}_{4}$ arabinose conformation. ${ }^{12}$ On the other hand, we observed 


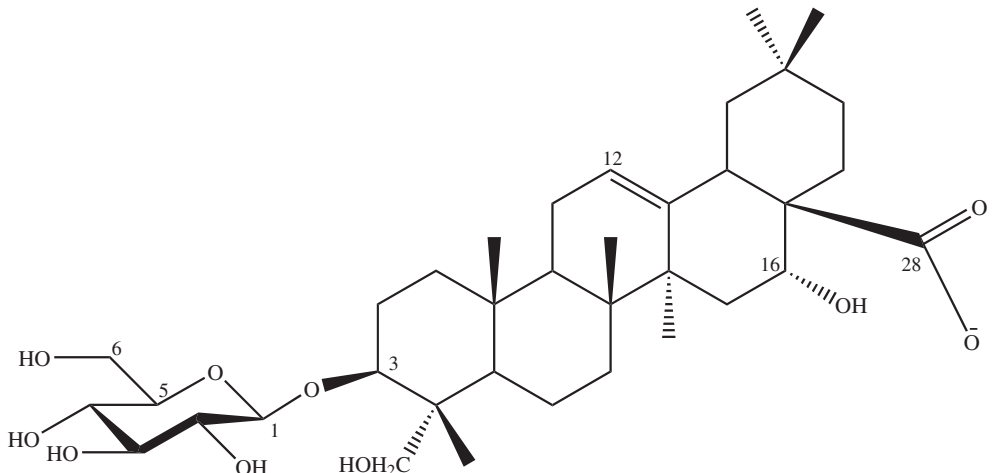

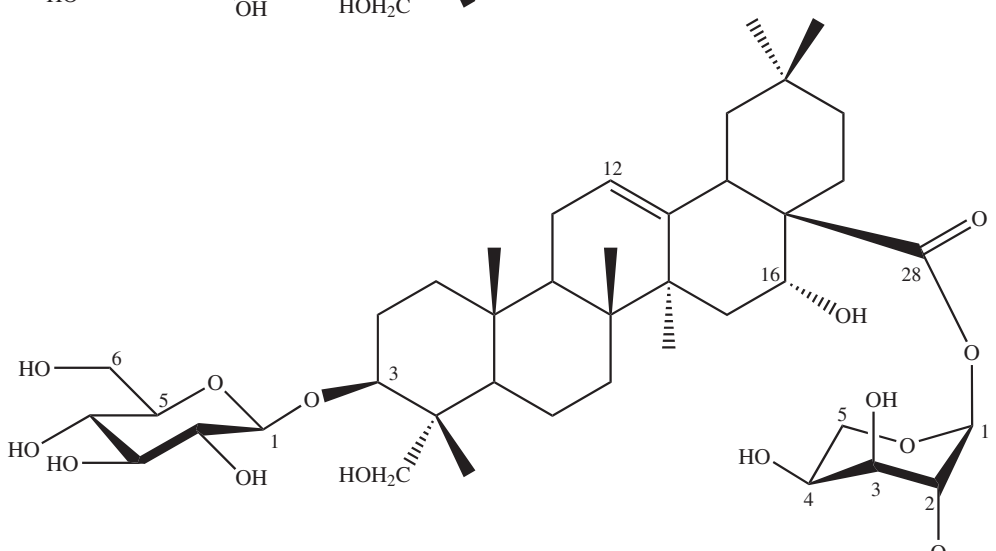

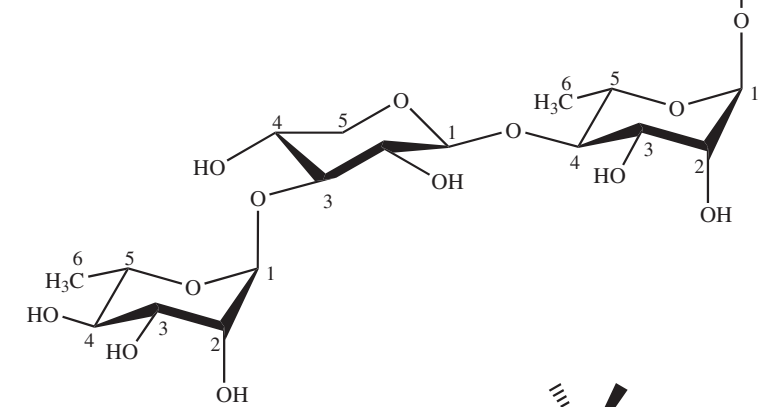

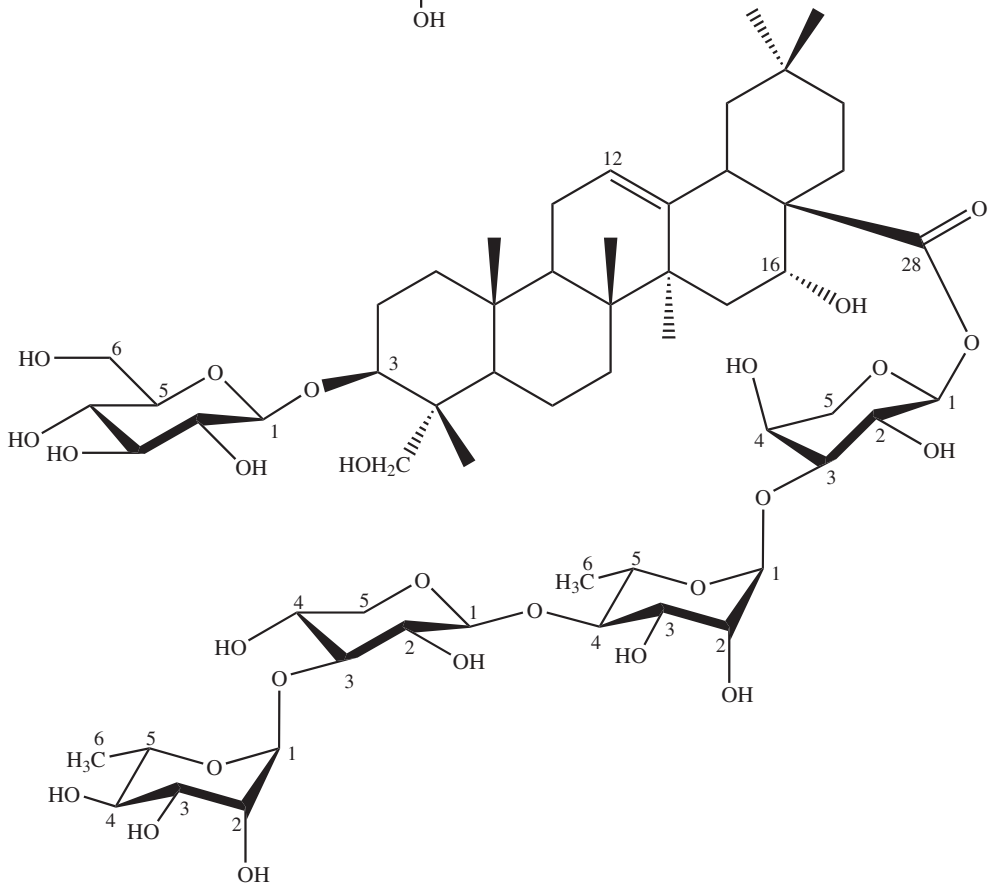

prosapogenin (1) 
in Lippiasaponin II a value of $5.2 \mathrm{~Hz}$ (Ara-H1) which suggests an $\alpha$-L-arabinopyranoside in ${ }^{4} \mathrm{C}_{1}$ conformation. ${ }^{12}$ The problem of the configuration and conformation of arabinopyranoses in esters of hindered triterpene carboxylic acids has been discussed at length using ${ }^{1} \mathrm{H}$ and ${ }^{13} \mathrm{C}$ NMR arguments. ${ }^{12,16}$ Particularly puzzling is the fact that in $\alpha$-L-arabinosyl ester the ${ }^{3} \mathrm{~J}_{\mathrm{H}-\mathrm{-}-\mathrm{H}-2}$ couplings vary from 2.8 to $6.2 \mathrm{~Hz}$ depending on the equilibrium between ${ }^{1} \mathrm{C}_{4}$ and ${ }^{4} \mathrm{C}_{1}$ conformations.

The $\alpha$-L-arabinopyranoside absolute stereochemistry was determined by comparison with methyl $\alpha$-Larabinopyranoside. ${ }^{17}$ The $\mathrm{C}-1$ of arabinopyranose in esters of triterpene carboxylic acids differs from C-1 of methyl $\alpha$-L-arabinopyranoside, because the priority order changes with the atomic number of atoms, therefore, the $\alpha$-L-arabinopyranoside is $S / R / S / S$. In the molecular model of compound $\mathbf{2}$ we observed that the dihedral angle between Ara-H1 and Ara-H2 is aproximately $80-90^{\circ}$ on $\alpha$-L-arabinopyranoside chair ${ }^{1} \mathrm{C}_{4}$ conformation, which explains the small $J$, in accordance with Karplus curve. The ${ }^{1} \mathrm{C}_{4}$ conformation on Lippiasaponin I (2) can be explained by $O$-Rha substituition at $\mathrm{C}-2$ in Ara, which increases the population of ${ }^{1} \mathrm{C}_{4}$ conformation. ${ }^{12}$ Additional proof was obtained through the observation of a $\mathrm{W}$ coupling between $\mathrm{H}-3(\delta 3.86)$ of arabinose and $\mathrm{H}-5(\delta 3.50)$.

In the molecular model of $\alpha$-L-arabinopyranoside chair ${ }^{4} \mathrm{C}_{1}$ conformation the dihedral angle between Ara-H1 and Ara-H2 is aproximately $180^{\circ}$, which points to a high value for the coupling constant. The predominance of ${ }^{4} \mathrm{C}_{1}$ conformation on Lippiasaponin II (3) can be explained by $O$-Rha substituition at C-3 in Ara, since the C-2 is hindered by the proximity of the $O$-substituent at position 1 .

Therefore, compound 3 was identified as $3-O-\beta-\mathrm{D}$ glucopyranosyl-28- $O$-( $\alpha$-L-rhamnopyranosyl- $(1 \rightarrow 3)-\beta$-Dxylopyranosyl- $(1 \rightarrow 4)-\alpha$-L-rhamnopyranosyl- $(1 \rightarrow 3)-\alpha-\mathrm{L}-$ arabinopyranosyl)-16 $\alpha, 23$-dihydroxy-olean-12-en-28-oic acid, and named Lippiasaponin II. To the best of our knowledge, this is the first report of the natural occurrence of $\mathbf{2}$ and $\mathbf{3}$.

\section{Experimental}

\section{General procedures}

NMR experiments were performed on a Bruker AM$500(500 \mathrm{MHz})$ spectrometer. NMR data were reported as $\delta$ values, and referenced to the residual signal of the solvent $\left(\mathrm{CD}_{3} \mathrm{OD}\right)$. The $\mathrm{MS}$ experiments were performed on a UltrOTOF-Q, Bruker Daltonics, Billerica, MA spectrometer (positive ion mode). Silica gel 60 (0.063$0.200 \mathrm{~mm}$, Merck) and silica gel 60 (0.040-0.063 mm,
Merck) were used for column chromatography. TLC was performed on precoated silica gel $60 \mathrm{~F}_{254}$ plates (Merck). HPLC separations were performed on a Shimadzu (FRC-10A) liquid chromatographer equipped with a UV-Vis detector using a preparative ODS column (column A, Shim-pack 20 x $250 \mathrm{~mm}$, Shimadzu; detector:

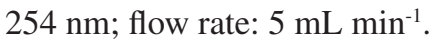

\section{Plant material}

Aerial parts of Lippia alba were collected in Cacupé, Florianópolis, Brazil, in April 2003. A voucher specimen (FLOR-31267) is deposited at the herbarium ICN (Federal University of Santa Catarina, Brazil).

\section{Extraction and isolation}

Material was dried and the leaves were separated from the stems and flowers. Leaves (840 g) were ground to powder and macerated two times with $96 \%$ ethanol. The alcohol extract (89.2 g) was concentrated, suspended in water, and then partitioned successively with petroleum ether (boiling range $30-60{ }^{\circ} \mathrm{C}$ ), $\mathrm{CH}_{2} \mathrm{Cl}_{2}$, EtOAc and $n-\mathrm{BuOH}$ (150 mL, 6 times with each solvent). The $n$-BuOHsoluble fraction $(2.8 \mathrm{~g})$ was applied to a silica gel 60 column (0.063-0.200 mm) eluting with the organic phase of the mixture EtOAc:MeOH: isopropanol: $\mathrm{H}_{2} \mathrm{O}: \mathrm{HOAc}$ $(7: 1: 2: 5: 0.2)$ to give five sub-fractions (1-5). Fraction 5 $(265 \mathrm{mg}$ ) was further chromatographed over silica gel 60 (0.040-0.063 mm), eluting with the mixture EtOH:EtOAc: $\mathrm{H}_{2} \mathrm{O}(120: 60: 5)$ to yield two sub-fractions (5.1-5.2). Fraction 5.1 (218 mg) was separated by preparative HPLC (column A) using $\mathrm{CH}_{3} \mathrm{CN}: \mathrm{H}_{2} \mathrm{O}, 70: 30$ (v:v) as eluant to yield $\mathbf{2}$ (35 $\mathrm{mg}$ ) and $\mathbf{3}$ (32 $\mathrm{mg})$.

\section{Acid hydrolysis of Lippiasaponin I (2)}

Compound 2 ( $2 \mathrm{mg}$ ) was hydrolyzed in $2 \mathrm{~mol} \mathrm{~L}^{-1}$ TFA at $120^{\circ} \mathrm{C}$ for $1 \mathrm{~h} 30 \mathrm{~min}$. The hydrolyzed monosaccharides were derivatized to the acetylated 1-deoxy-1-(2hydroxypropylamino) alditols following published procedures $^{12}$ and analysed by GC using a Hewlett-Packard Ultra-2 column $(50 \mathrm{~m} \times 0.2 \mathrm{~mm}$, thickness of liquid phase $0.11 \mu \mathrm{m})$ and identified by coinjection with authentic standards prepared in a similar way.

\section{Prosapogenin (1)}

White powder, ${ }^{1} \mathrm{H}$ NMR and ${ }^{13} \mathrm{C}$ NMR spectral data: see Table 1. 


\section{Lippiasaponin I (2)}

White powder, $[\alpha]_{\mathrm{D}}^{25}=-30.43(\mathrm{C}=0.013, \mathrm{MeOH})$; FAB MS $m / z=1229(100 \%) ; 1050(10 \%) ;{ }^{1} \mathrm{H}$ NMR and ${ }^{13} \mathrm{C}$ NMR spectral data: see Table 1.

Lippiasaponin II (3)

White powder; ${ }^{1} \mathrm{H}$ NMR and ${ }^{13} \mathrm{C}$ NMR spectral data: Table 1.

\section{Supplementary Information}

Supplementary data are available free of charge at http://jbcs.sbq.org.br, as PDF file.

\section{Acknowledgments}

We are indebted to Lic. Diego Navarro (Facultad de Ciencias Exactas y Naturales, Universidad de Buenos Aires) for his help with the preparation of sugar derivatives and GC analysis and to Prof. Norberto Peporine Lopes (Faculdade de Ciências Farmacêuticas, USP - Ribeirão Preto) for the mass spectral meseasurements.

\section{References}

1. Holetz, F. B.; Pessini, G. L.; Sanches, N. R.; Cortez, D. A. G.; Nakamura, C. V.; Dias Filho, B. P.; Mem. Inst. Oswaldo Cruz 2002, 97, 1027.

2. Duarte, M. C. T.; Figueira, G. M.; Sartoratto, A.; Rehder, V. L. G.; Delarmelina, C.; J. Ethnopharmacol. 2005, 97, 305.
3. Andrighetti-Frohner, C. R; Sincero, T. C. M; Da Silva, A. C.; Savi, L. A.; Gaido, C. M.; Bettega, J. M. R.; Mancini, M.; De Almeida, M. T. R.; Barbosa, R. A.; Farias, M. R.; Barardi, C. R. M; Simões, C. M. O.; Fitoterapia 2005, 76, 374.

4. Zétola, M.; De Lima, T. C. M.; Sonaglio, D.; GonzálezOrtega, G.; Limberger, R. P.; Petrovick, P. R.; Bassani, V. L.; J. Ethnopharmacol. 2002, 82, 207.

5. Pascual, M. E.; Slowing, K.; Carretero, E.; Villar, A.; Il Farmaco 2001, 56, 501.

6. Matos, F. J. A.; Rev. Bras. Farm. 1996, 77, 137.

7. Barbosa, F. G.; Lima, M. A.; Silveira, E. R.; Magn. Reson. Chem. 2005, 43, 334.

8. Barbosa, F. G.; Lima, M. A. S.; Braz-Filho, R., Silveira, E. R.; Biochem. Syst. Ecol. 2006, 34, 819.

9. Pascual, M. E.; Slowing, K.; Carretero, E.; Sanchez Mata, D.; Villar, A.; J. Ethnopharmacol. 2001, 76, 201.

10. Tan, N.; Zhou, J.; Zhao, S.; Phytochemistry 1999, 52, 153.

11. Zhang, Y.-J.; Yang, C.-R.; Phytochemistry 1994, 36, 997.

12. Ishii, H.; Kitagawa, I.; Matsushita, K.; Shirakawa, K.; Tori, K.; Tozyo, T.; Yoshikawa, M.; Yoshimura, Y.; Tetrahedron Lett. 1981, 22, 1529 .

13. Cases, M. R.; Cerezo, A. S.; Stortz, C. A.; Carbohydr. Res. 1995, 269, 333

14. Eskander, J.; Lavaud, C.; Pouny, I.; Soliman, H. S. M.; AbdelKhalik, S. M.; Mahmoud, I. I.; Phytochemistry 2006, 67, 1793.

15. Sahu, N. P.; Koike, K.; Jia, Z.; Nikaido, T.; Phytochemistry 1997, 44, 1145

16. Massiot, G.; Lavaud, C.; Besson, V.; Men-Olivier, L. L.; Binst, G. V.; J. Agric. Food Chem. 1991, 39, 78.

17. Taniguchi, T.; Monde, K.; Miura N.; Nishimura, S.-I.; Tetrahedron Lett. 2004, 45, 8451.

Received: September 30, 2008 Web Release Date: March 11, 2010 


\section{Triterpenoid Saponins from Lippia alba (Mill.) N. E. Brown}

\section{Mareni R. Farias, ${ }^{* a}$ Roberto Pértile, ${ }^{a}$ Melissa M. Correa, ${ }^{a}$ Maria Tereza R. de Almeida, ${ }^{b}$ Jorge A. Palermo ${ }^{b}$ and Eloir P. Schenkel ${ }^{a}$}

${ }^{a}$ Programa de Pós-graduação em Farmácia, Universidade Federal de Santa Catarina - Campus

Universitário Trindade, 88040-900 Florianópolis-SC, Brasil and Departamento de Ciências

Farmacêuticas, Universidade Federal de Santa Catarina, 88040-900 Florianópolis-SC, Brazil

${ }^{b}$ Departamento de Química Orgánica, Facultad de Ciencias Exactas y Naturales, Universidad de Buenos Aires, Ciudad Universitaria Pab.2, C1428EGA, Buenos Aires, Argentina

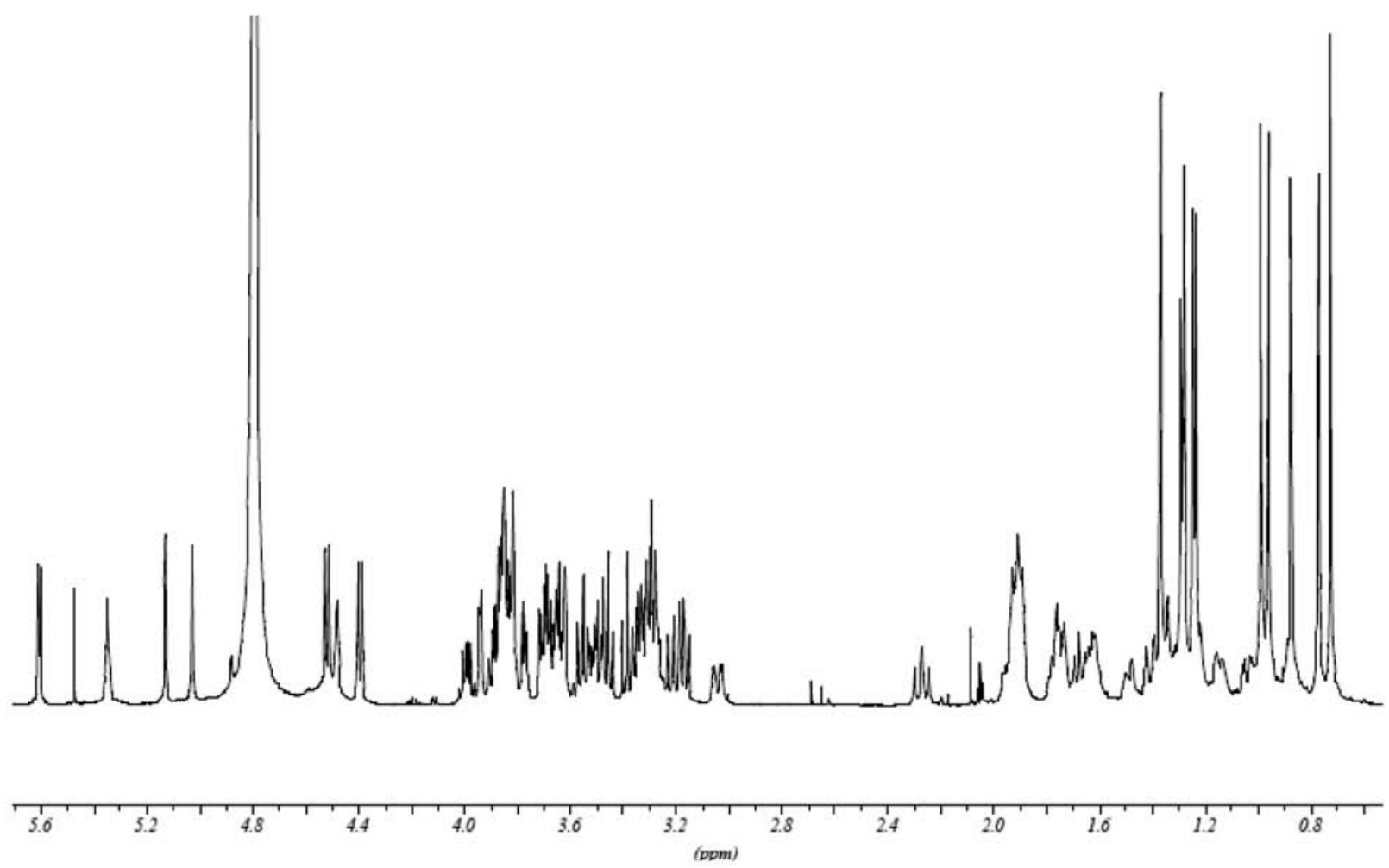

Figure S1. ${ }^{1} \mathrm{H}$ NMR spectrum (500 MHz, $\mathrm{CD}_{3} \mathrm{OD}$ ) of Lippiasaponin I (2). 

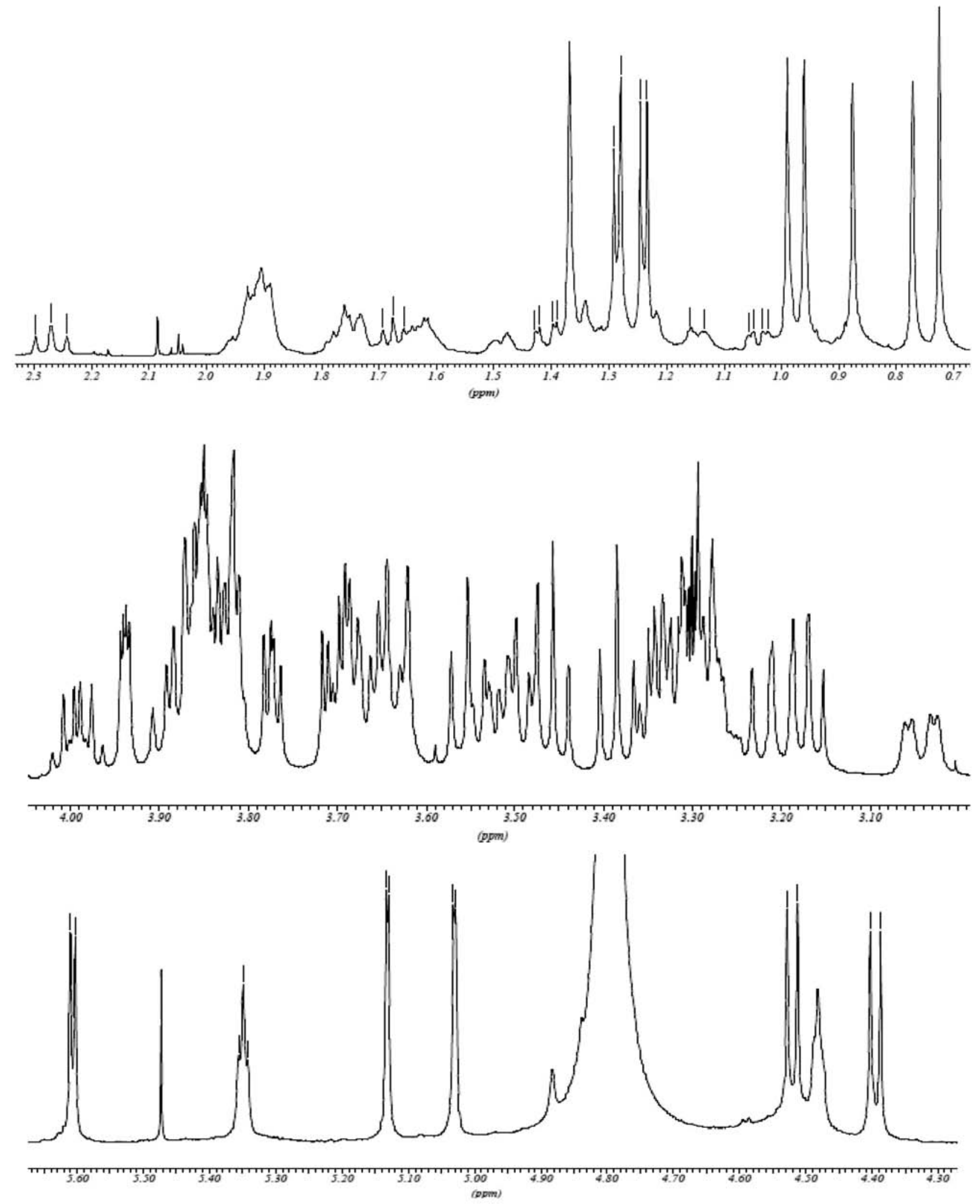

Figure S2. Expansions of the ${ }^{1} \mathrm{H}$ NMR spectrum (500 MHz, $\left.\mathrm{CD}_{3} \mathrm{OD}\right)$ of Lippiasaponin I (2). 


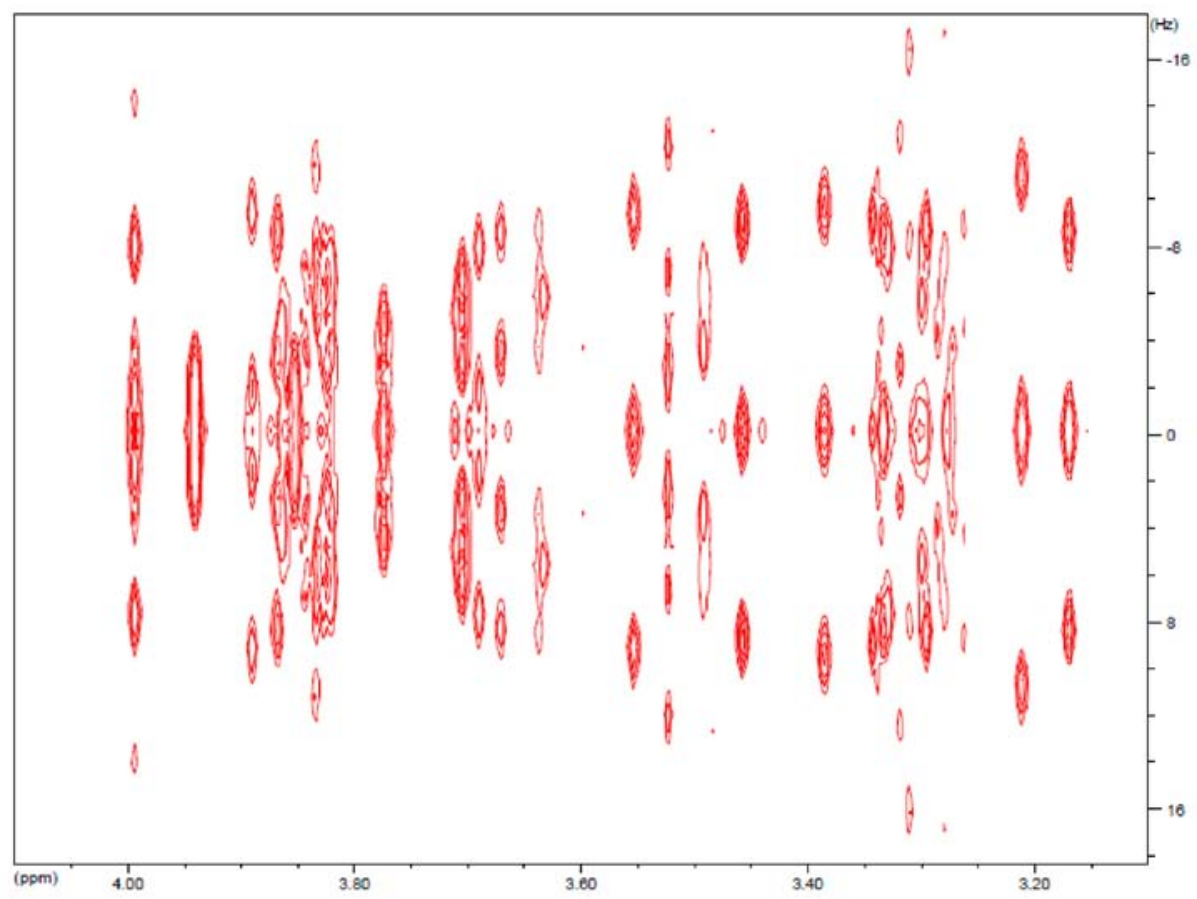

Figure S3. 2D J-Resolved spectrum (500 MHz, in $\mathrm{CD}_{3} \mathrm{OD}$ ) of Lippiasaponin I (2).

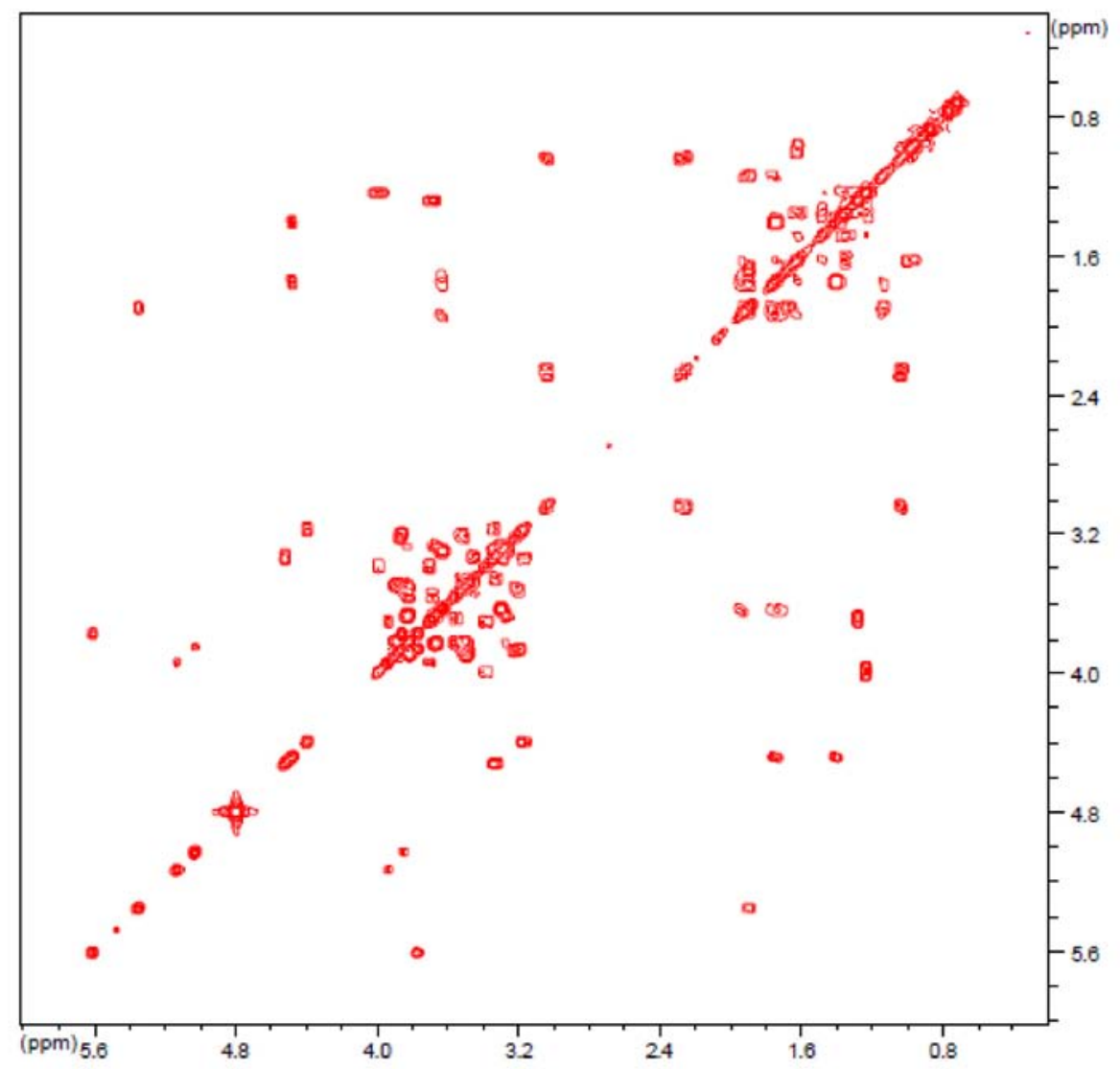

Figure S4. ${ }^{1} \mathrm{H}-{ }^{-1} \mathrm{H}$ COSY spectrum $\left(500 \mathrm{MHz}\right.$, in $\left.\mathrm{CD}_{3} \mathrm{OD}\right)$ of Lippiasaponin I (2). 


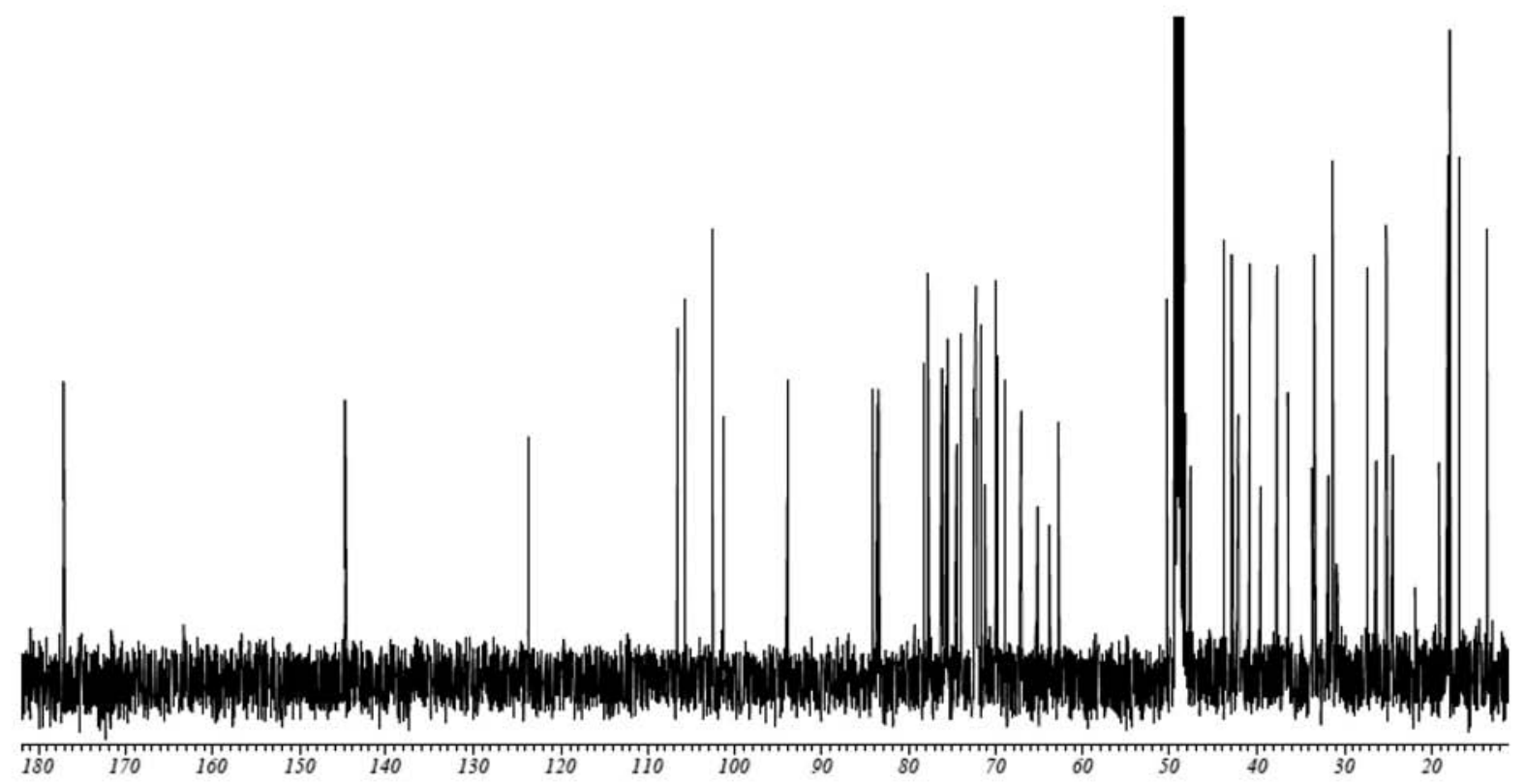

Figure S5. ${ }^{13} \mathrm{C}$ NMR spectrum $\left(125 \mathrm{MHz}\right.$, in $\left.\mathrm{CD}_{3} \mathrm{OD}\right)$ of Lippiasaponin I (2).

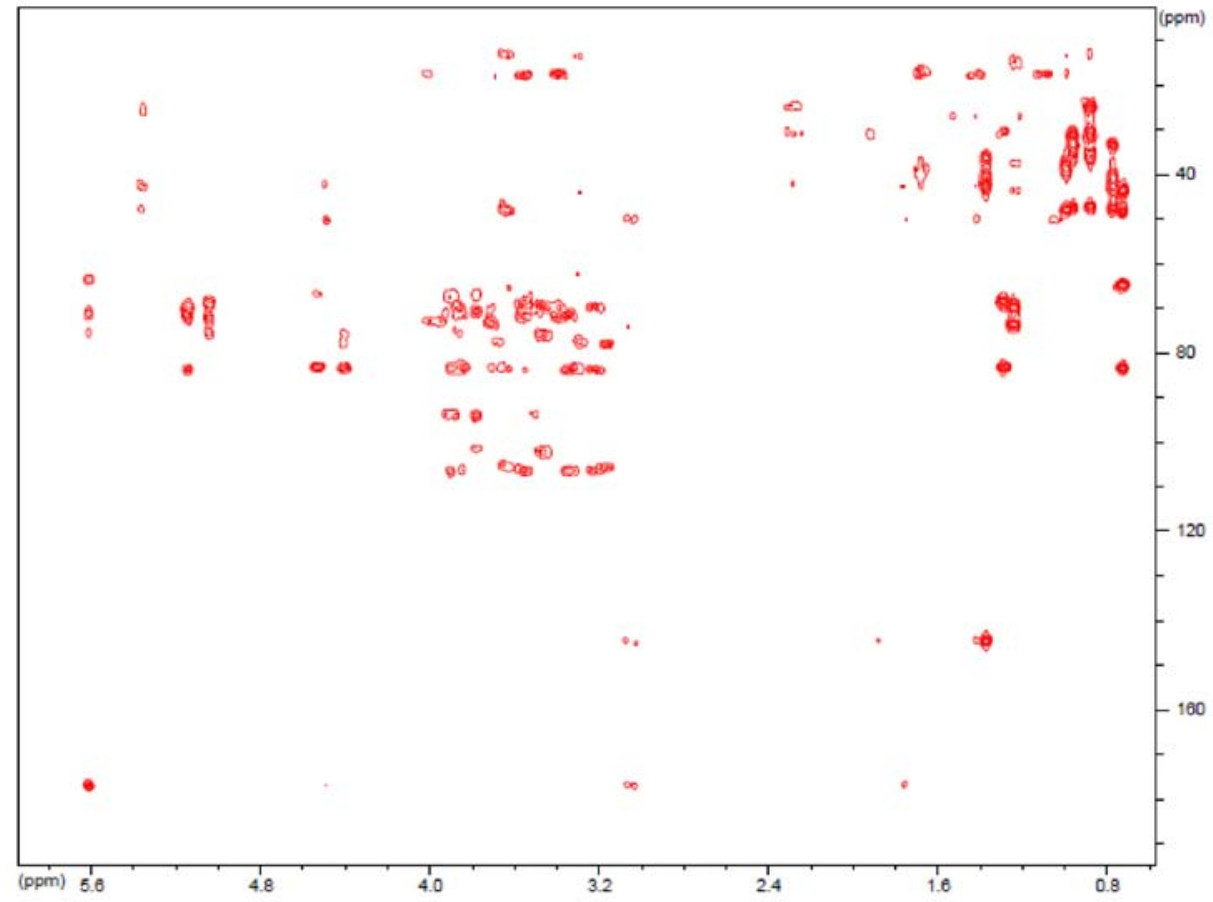

Figure S6. HMBC spectrum (125 MHz, in $\left.\mathrm{CD}_{3} \mathrm{OD}\right)$ of Lippiasaponin I (2). 


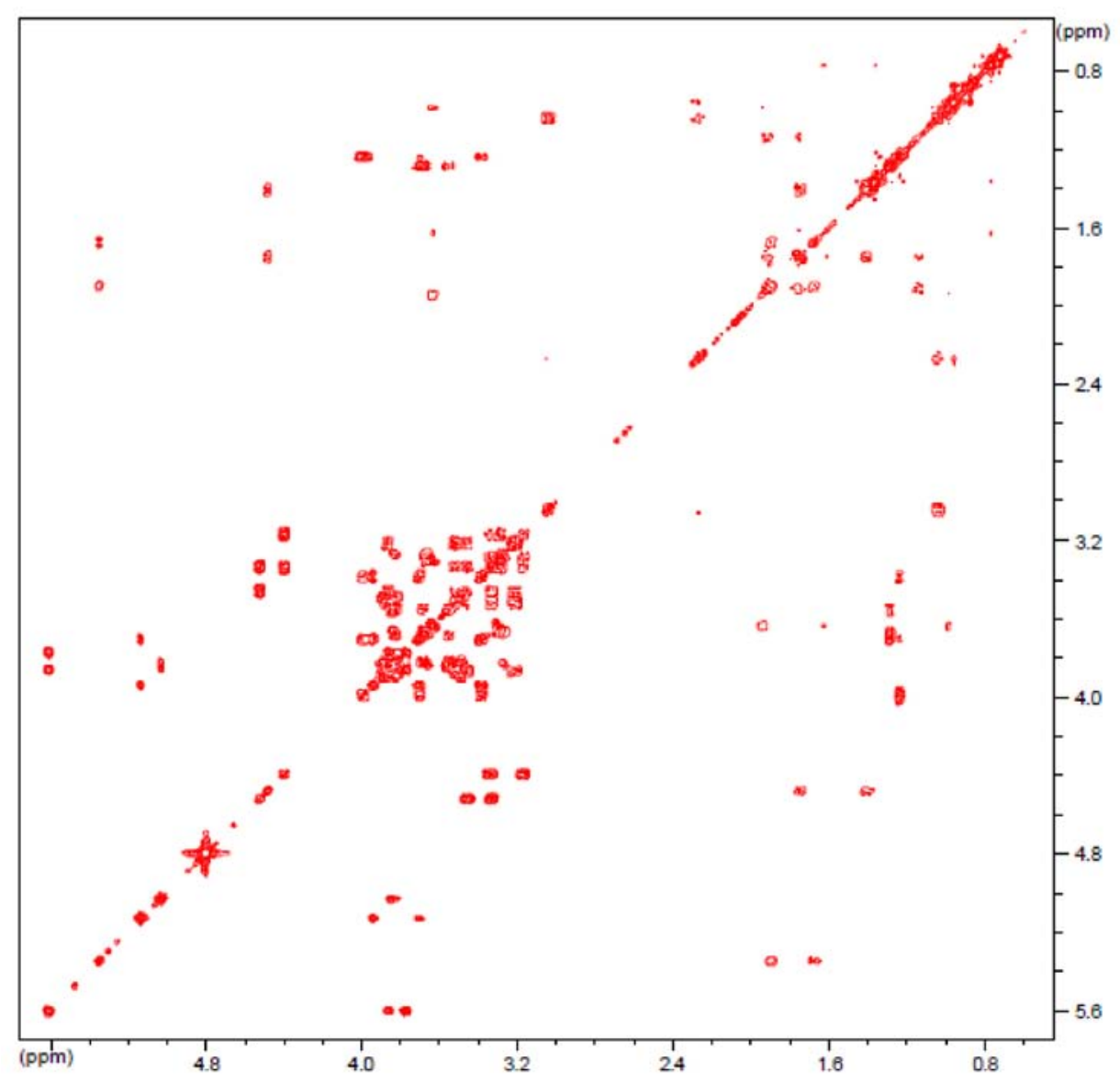

Figure S7. RCT spectrum (500 MHz, in $\mathrm{CD}_{3} \mathrm{OD}$ ) of Lippiasaponin I (2).

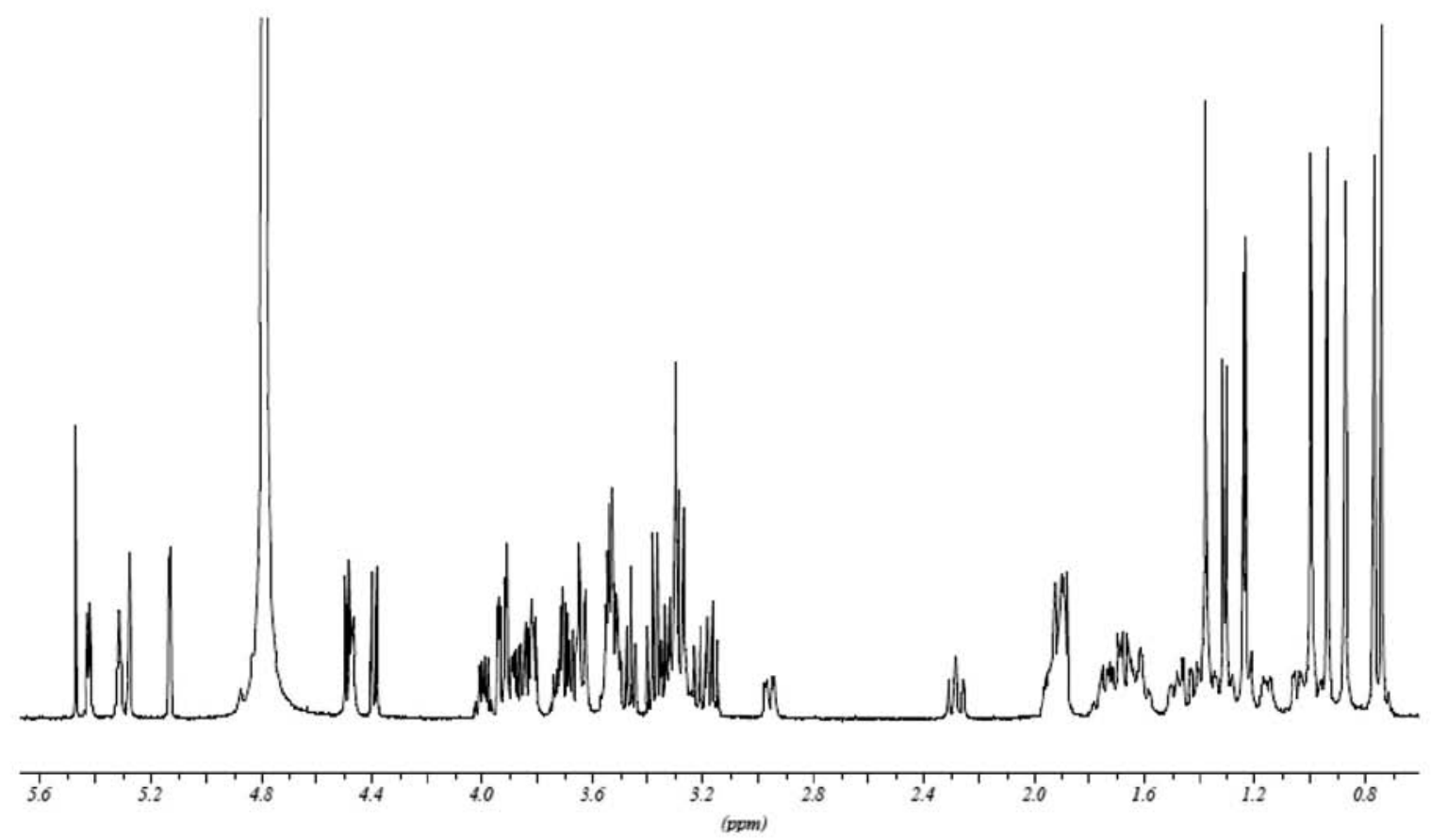

Figure S8. ${ }^{1} \mathrm{H}$ NMR spectrum (500 MHz, $\mathrm{CD}_{3} \mathrm{OD}$ ) of Lippiasaponin II (3). 

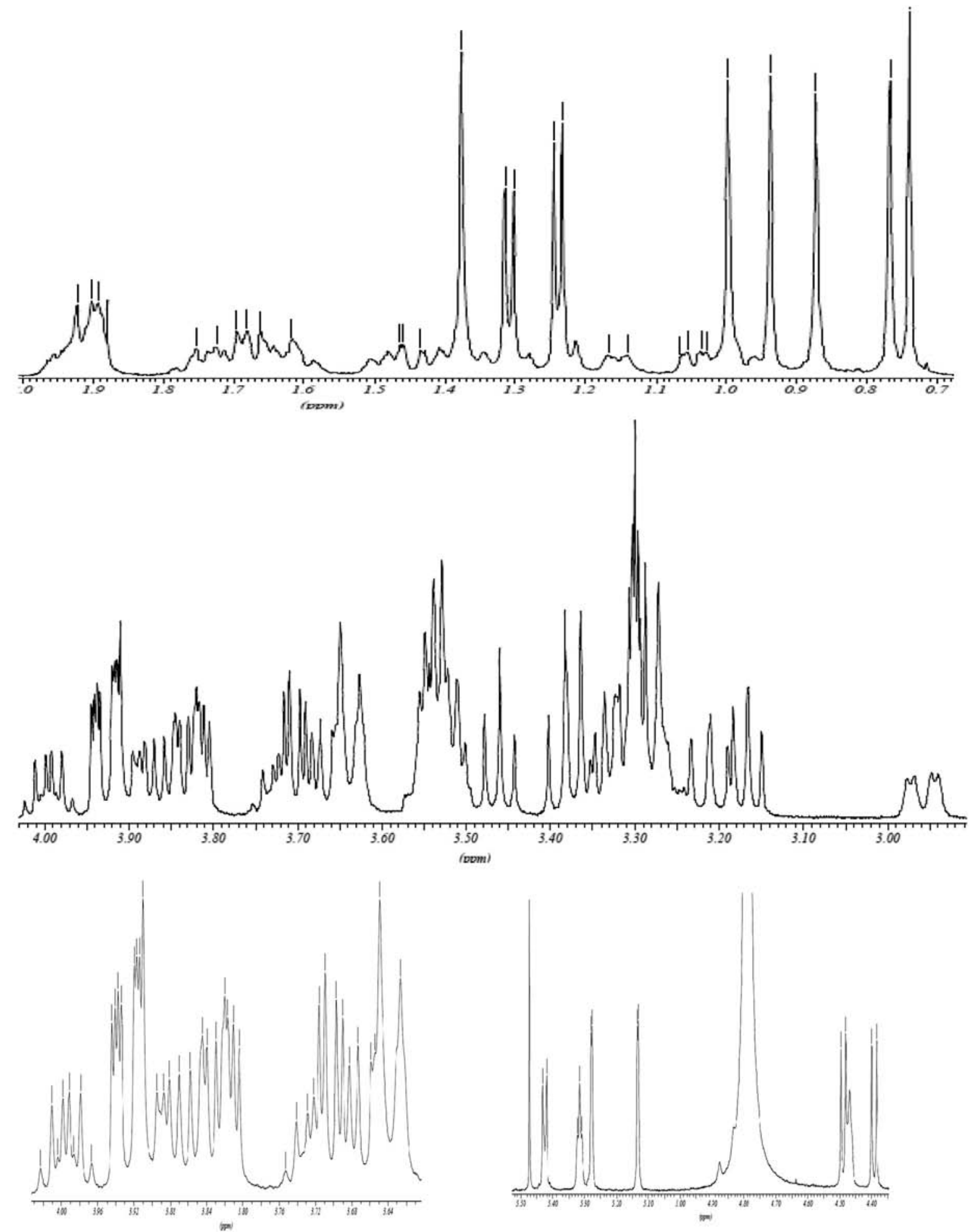

Figure S9. Expansions of the ${ }^{1} \mathrm{H}$ NMR spectrum (500 $\mathrm{MHz}, \mathrm{CD}_{3} \mathrm{OD}$ ) of Lippiasaponin II (3). 


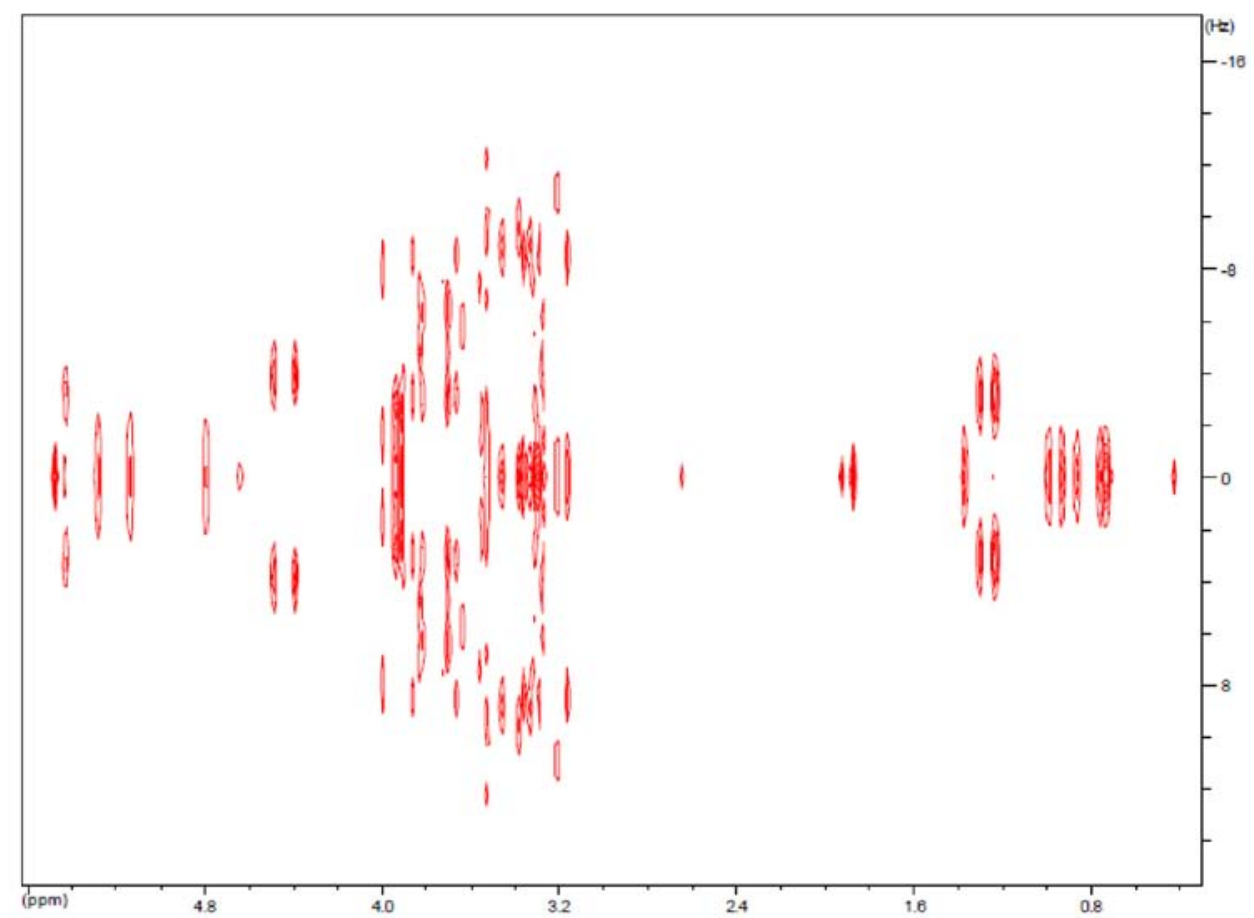

Figure S10. 2D J-Resolved spectrum (500 MHz, in $\left.\mathrm{CD}_{3} \mathrm{OD}\right)$ of Lippiasaponin II (3).

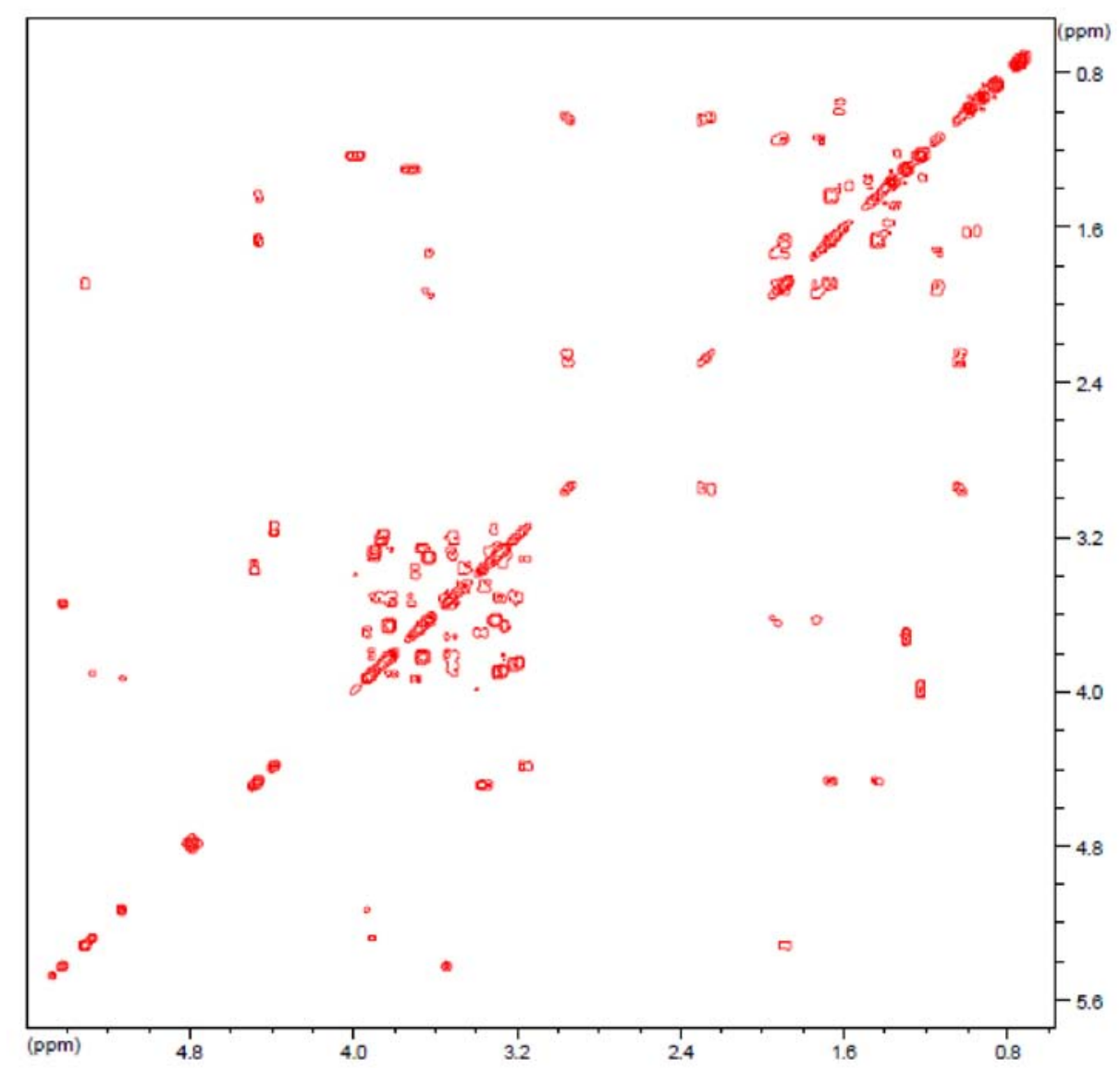

Figure S11. ${ }^{1} \mathrm{H}-{ }^{1} \mathrm{H}$ COSY spectrum (500 MHz, in $\left.\mathrm{CD}_{3} \mathrm{OD}\right)$ of Lippiasaponin II (3). 


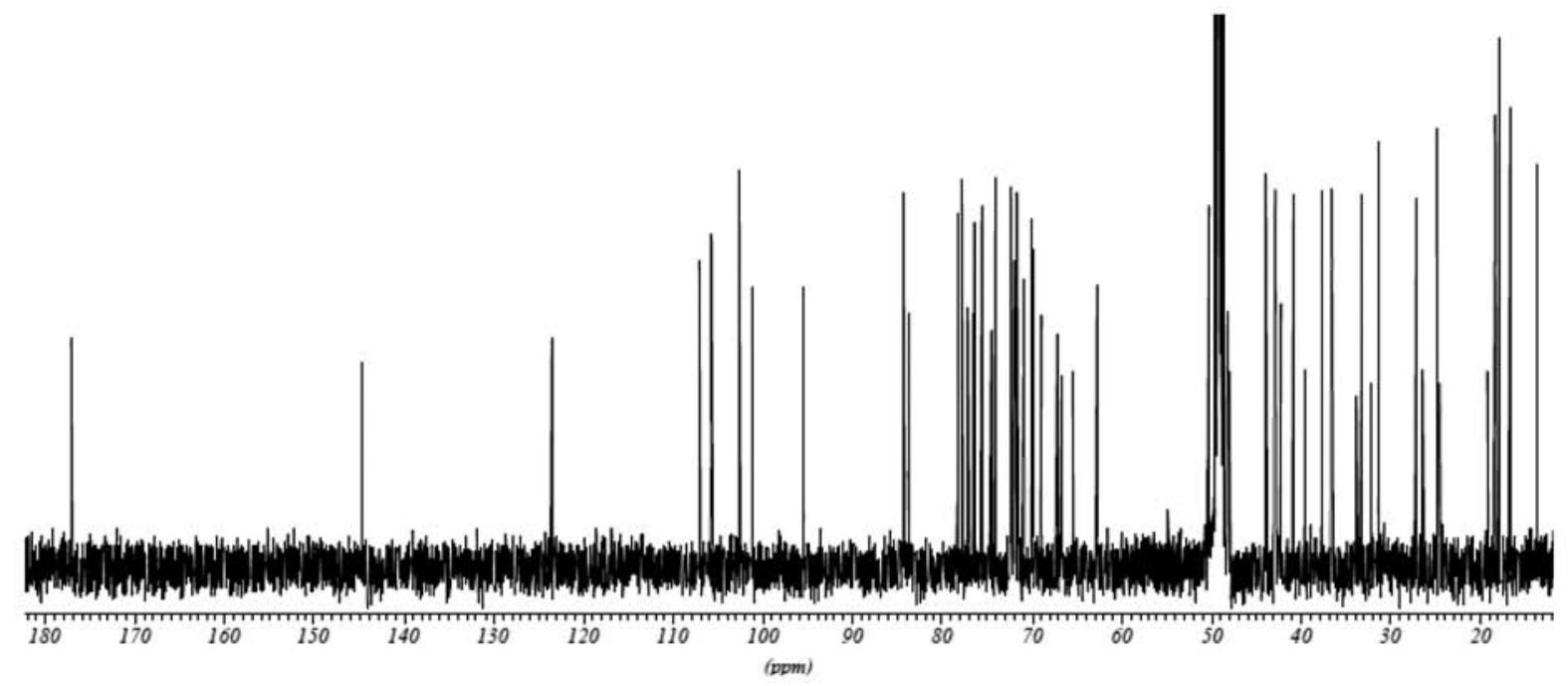

Figure S12. ${ }^{13} \mathrm{C}$ NMR spectrum $\left(125 \mathrm{MHz}\right.$, in $\left.\mathrm{CD}_{3} \mathrm{OD}\right)$ of Lippiasaponin II (3).

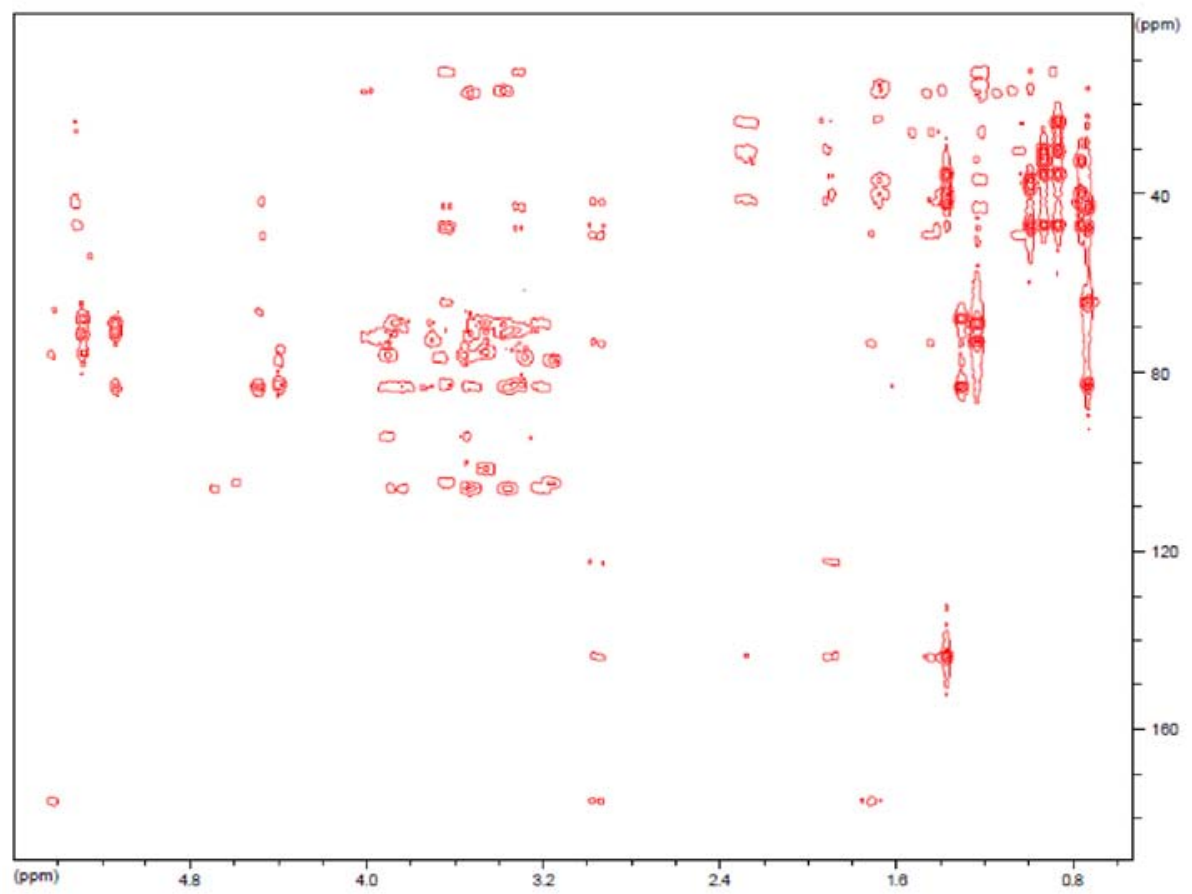

Figure S13. HMBC spectrum (125 MHz, in $\mathrm{CD}_{3} \mathrm{OD}$ ) of Lippiasaponin II (3). 


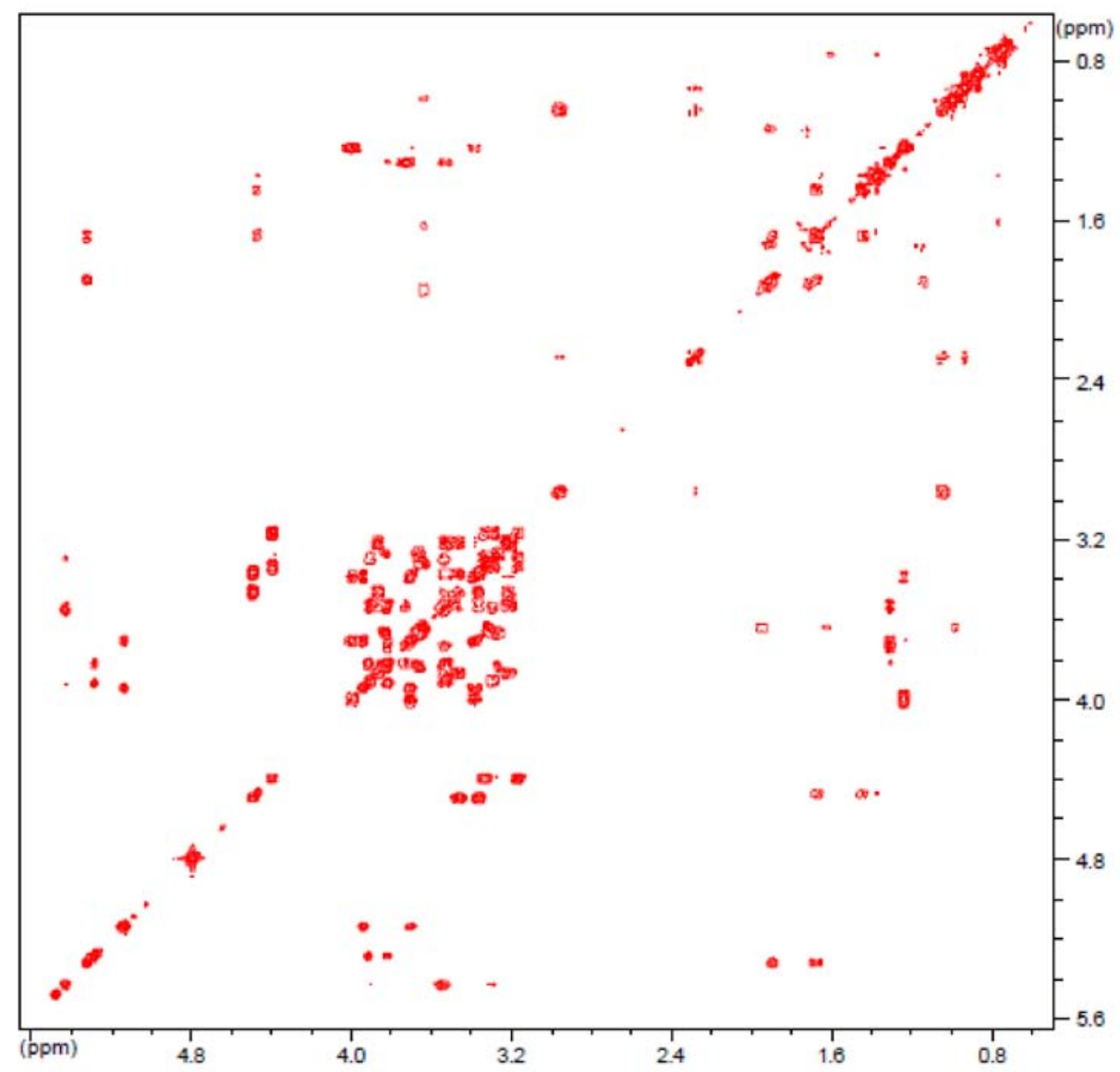

Figure S14. RCT spectrum (500 MHz, in $\mathrm{CD}_{3} \mathrm{OD}$ ) of Lippiasaponin II (3). 